\title{
Preparation and Characterization of Nanocomposites Based on Linear Medium Density Polyethylene/Cellulose Nanofibers from Agave tequilana Bagasse Waste
}

José Guillermo Torres-Rendón, ${ }^{a}$ Mario E. Valdez-Fausto, ${ }^{\mathrm{b}}$ José Anzaldo-Hernández, ${ }^{\mathrm{a}}$ Rosa M. Jiménez-Amezcua, ${ }^{b}$ Kestur G. Satyanarayana, ${ }^{c}$ Salvador García-Enriquez, ${ }^{\mathrm{a}}$ and María Guadalupe Lomelí-Ramírez ${ }^{\mathrm{a}, *}$

In the Mexican state of Jalisco, a significant amount of fibrous agave waste is generated from the tequila industry every year. The objective of this study was to establish the potential of obtaining cellulose nanofibers (CNF) from the bagasse waste of Agave tequilana, and then incorporate them into a linear medium density polyethylene matrix to obtain nanocomposites through the thermocompression process. These nanoparticles were used to prepare nanocomposites of the selected matrix, incorporating 1 to $5 \mathrm{wt} \%$ of CNF. All of the prepared composites had a low water absorption. Increases in tensile strength and in modulus and flexural properties occurred when the concentration of the CNF was augmented. However, in the case of nanocomposites with $5 \mathrm{wt} \%$, a decrease in elongation was observed.

Keywords: Agave tequilana waste; Nanocomposite; Thermocompression moulding; Cellulose nanofibers

Contact information: a: Departament of Wood, Cellulose and Paper, University of Guadalajara, $\mathrm{km} 15.5$ at the Guadalajara-Nogales Highway, Postal Code 45220, Zapopan, Mexico; b: Department of Chemical Engineering, University of Guadalajara, Marcelino Garcia Barragan 1451, Postal Code 44430, Guadalajara, Mexico; c: Present Address: Honorary Professor, Poornaprajna Institute of Scientific Research, Sy. No. 167, Poornaprajnapura, Bidalur Post, Devanahalli, Bengaluru-562110, Karnataka, India; *Corresponding author: glomeli@dmcyp.cucei.udg.mx

\section{INTRODUCTION}

Industrialized countries are continually in search of raw materials, processes, and products for various technological applications. Such materials should be sustainable, low cost, low-polluting, and have good mechanical performance. Composites, particularly those that use lignocellulosic fibers, have these characteristics; therefore, there has been increased interest for these areas due to the benefits these composites offer (Khalil et al. 2012).

Natural fibers have been used in the production of value-added products, especially as reinforcements in polymer matrices for the production of composite materials (Zhang et al. 2013). It has been reported that the addition of natural fibers into a polymer matrix improves certain properties, such as the tensile and flexural properties, of the resulting composite (Darabi et al. 2012). The main advantages of using reinforcements obtained from renewable sources, in comparison with inorganic fillers, are their abundance, low density, high reinforcement capacity, low energy consumption, high specific mechanical properties, biodegradability, and the large amount of lignocellulosic material available in nature. However, they also have the disadvantage of having hydrophilic character. The hydroxyl groups that are present in these materials interact with water molecules. This affects the compatibility of the natural fibers with the hydrophobic polymer matrices, resulting in low matrix-reinforcing adhesion. Consequently, the physico-mechanical 
properties and the resistance to environmental and biological deterioration of composite materials are affected, thus reducing their potential applications (Cao et al. 2012).

The generation of large quantities of agricultural waste by various industries has given rise to a prevailing need to take advantage of these ligno-cellulosic resources as raw materials. There is also a need to incorporate them into a production chain, which allows for the development of new products, such as composite materials using innovative techniques and processes, for the benefit of society and the environment (Satyanarayana $e t$ al. 2004; Thakur et al. 2017). This is the case with agave bagasse, which is a by-product that is generated by the industrial production of tequila. In Mexico, the consumption of about 649,000 tons of agave was reported in 2017, of which about 463,000 tons corresponded specifically to agave bagasse (Tequila Regulatory Counsel, 2017). This fibrous material is hardly used in the region of Tequila, Jalisco, as it is considered an industrial waste. This suggests that due to its lignocellulosic nature, the agave bagasse can be considered a raw material for producing composite materials, with a high potential for the generation of cellulose microfibrils. In fact, while the blue agave bagasse fibers of Mexico have been characterized for their physical, chemical, mechanical, and thermal properties (Satyanarayana et al. 2013), there have also been many studies using agave bagasse fiber and even Agave tequilana bagasse fiber particularly in the development of polymer-based composites (Idarraga et al. 1999; Santiago et al. 2002; Tronc et al. 2007; Leduc et al. 2008; Saucedo-Luna et al. 2010; Becerra-Rodríguez et al. 2011; LópezBañuelos et al. 2012; Abreu-Sherrer 2013; Frausto-Gutierrez et al. 2015; Cisneros-López et al. 2017). For example, studies of acid (Saucedo-Luna et al. 2010; Abreu-Sherrer 2013) and alkaline (Idarraga et al. 1999; Santiago et al. 2002) hydrolysis of agave bagasse fibers have been reported with a cellulose yield of 40 to $45 \mathrm{wt} \%$, a hemicellulose yield of 20 to $22 \mathrm{wt} \%$, and a lignin yield of $15 \mathrm{wt} \%$. Studies on water absorption of low-density polyethylene (LDPE)-agave fiber composites have been reported by Becerra-Rodríguez et al. (2011). Similarly, studies of linear medium density polyethylene (LMDPE) composites with 15 wt\% barley particles were reported by Frausto et al. (2015). Also, mechanical properties (tensile, flexural, and impact) of different polymer-based composites containing raw agave tequilana fibers (with and without chemical treatment) have been reported by several researchers (Tronc et al. 2007; Leduc et al. 2008; López-Bañuelos et al. 2012; Cisneros-López et al. 2017). There is also one study on the mechanical properties of highdensity polyethylene (HDPE) containing agave-coconut fibers with two fiber contents (20 and $30 \mathrm{wt} \%$ ) and different coconut-agave fiber ratios processed by a two-stage process using a twin-screw extruder followed by injection molding (Pérez-Fonseca et al. 2016). However, there seems to have been no study on the preparation of nanofibers of $A$. tequilana bagasse fiber and their polymeric composites. The present study focuses on this aspect.

In contrast, nanocellulose is being considered as the next generation of renewable reinforcement for the formation of high performance biocomposites (Lee et al. 2014). Based on its dimensions, functions, preparation methods, and source of cellulose, nanocellulose is classified into three categories according to Klemm et al. (2011): nanofibrillated cellulose (NCF or CNF), nanocrystalline cellulose (NCC or CNC), and bacterial nanocellulose (BNC). Cellulose nanofibers are obtained from lignocellulosic materials, such as wood and agricultural crops, by different processing methods such as chemical processing, mechanical methods, a combination of these, etc. In general, lignin is also removed from the plant cell wall before fibrillation using chemical treatment. Depending on the source and separation method used, the cellulose nanofibers are typically between 20 to $40 \mathrm{~nm}$ in diameter and several microns in length. Due to the specific 
characteristics of cellulose nanofibers, such as a high surface area layout and good dispersion, they are of great interest for use in the improvement of the properties of polymers (Hietala et al. 2013). Accordingly, cellulose nanofibers of A. tequilana bagasse fiber were prepared in this study to develop nanocomposites with a LMDPE matrix.

From the foregoing, the following became clear, leading to the scientific gaps that exist despite the large volume of literature in books and review articles (Dufresene 2010; Cai and Niska 2011; Kalia et al. 2011a,b; Mariano et al. 2014; Satyanarayana et al. 2017; Thakur et al. 2017):

(i) A large amount of $A$. tequilana bagasse fiber is available as waste, which can be used to develop value added products; (ii) The unique properties of LMDPE have not been used in the preparation of composites, including nanocomposites; (iii) There are not many reports on the preparation of cellulose nanofibers using A. tequilana bagasse fiber; (iv) Although there are several studies on the development of polymeric composites using $A$. tequilana bagasse fibers, there is not a lot available on the development of composites, including nanocomposites, using LMDPE as a matrix; and, (v) The use of an inexpensive and easy thermocompression process in the preparation of the previously mentioned nanocomposites. objectives:

Accordingly, this study was conducted to address these gaps with the following

(i) Preparing and characterizing cellulose nanofibers (CNF) using the waste of $A$. tequilana bagasse fiber;

(ii) Preparing and characterizing nanocomposites using LMDPE as a matrix and different amounts ( 1 to $5 \mathrm{wt} \%$ ) of prepared CNF from A. tequilana bagasse fiber; and

(iii) Comparing the obtained properties of these nanocomposites with the reported results on macro-composites based on A. tequilana bagasse fibers and some of the nanofibers from other plant fibers.

It is hoped that the results of this study will not only help in finding applications for the developed nanocomposites, but also lead to further research on nanocomposites based on other nanofibers obtained from agricultural wastes of other plant materials.

\section{EXPERIMENTAL}

\section{Materials}

Bagasse of the Weber blue variety of the A. tequilana was purchased from Mundo Agave in Jalisco, Mexico. LMDPE R093650 was used as the polymer matrix and was supplied by Polímeros Nacionales (Mexico). This polymer has a melt flow index of $5 \mathrm{~g} / 10$ $\min \left(2.16 \mathrm{~kg} / 190{ }^{\circ} \mathrm{C}\right)$ and a density of $0.93 \mathrm{~g} / \mathrm{cm}^{3}$. Other chemicals used in the study include: hydrochloric acid $(\mathrm{HCl}, 37 \%)$, hydrogen peroxide $\left(\mathrm{H}_{2} \mathrm{O}_{2}, 30 \%\right)$, sodium hypochlorite $(\mathrm{NaOCl}, 13 \%)$, sodium bromide $(\mathrm{NaBr}, 97 \%)$, sulfuric acid $\left(\mathrm{H}_{2} \mathrm{SO}_{4}, 95 \%\right)$, and sodium hydroxide $(\mathrm{NaOH}, 97 \%)$. All of these chemicals were acquired from Karal (León, Mexico). Anthraquinone (AQ, 97\%), sodium chlorite $\left(\mathrm{NaClO}_{2}, 90 \%\right)$, and 2,2,6tetramethylpiperidine-1-oxyl radical (TEMPO, 98\%) were purchased from Sigma-Aldrich (Toluca, Mexico). 


\section{Methods}

Preparation of bleached cellulosic fibers

First, acid hydrolysis was carried out on the agave bagasse using a $0.5 \% \mathrm{H}_{2} \mathrm{SO}_{4}$ solution (hydromodule of 8:1) in a rotary digester at $160{ }^{\circ} \mathrm{C}$ for $30 \mathrm{~min}$. Afterwards, the hydrolyzed bagasse was cooked using a solution of anthraquinone $(0.1 \%$, hydromodule of 5:1) and $\mathrm{NaOH}(23.2 \%)$ in a rotary digester at $170{ }^{\circ} \mathrm{C}$ for $150 \mathrm{~min}$. These cooking conditions were based on those reported by Lomelí-Ramírez et al. (2018). The resulting cooked pulp was washed and purified. The bleaching process was performed by conducting four sequential chemical treatments.

The first treatment was performed in the presence of a chlorine dioxide solution (D0). The components of this process were $10 \mathrm{wt} \%$ pulp, $1.7 \mathrm{wt} \% \mathrm{ClO}_{2}, 0.15 \mathrm{wt} \% \mathrm{HCl} 1$ $\mathrm{N}$. The treatment was conducted at $60{ }^{\circ} \mathrm{C}$ for $30 \mathrm{~min}$, and it resulted in a final $\mathrm{pH}$ between 2 and 3. The second step was an alkaline extraction (E) on the $10 \mathrm{wt} \%$ pulp used in the previous treatment. For this treatment, a solution of $\mathrm{NaOH}(5 \mathrm{wt} \%) 1 \mathrm{~N}$ was employed. The alkaline extraction was performed at $70{ }^{\circ} \mathrm{C}$ for $60 \mathrm{~min}$, with a final $\mathrm{pH}$ of $\geq 10.5$.

In the third treatment, chlorine dioxide (Dl) was added $\left(1 \mathrm{wt} \% \mathrm{ClO}_{2}\right)$ with $0.15 \mathrm{wt} \%$ of $\mathrm{NaOH} 1 \mathrm{~N}$. The process was conducted at $80^{\circ} \mathrm{C}$ for $180 \mathrm{~min}$.

In the fourth treatment, $1.5 \mathrm{wt} \%$ hydrogen peroxide and $1 \mathrm{wt} \% \mathrm{NaOH} 1 \mathrm{~N}$ was added to obtain an initial $\mathrm{pH}$ between 11.5 and 11.8. This step was performed at $80{ }^{\circ} \mathrm{C}$ for 180 min. Lastly, with the aim to eliminate hemicelluloses, a chemical treatment was performed using $0.5 \mathrm{~g}$ of $\mathrm{NaOH}$ for each $100 \mathrm{~g}$ of pulp (dry based) at $25^{\circ} \mathrm{C}$ for $30 \mathrm{~min}$.

\section{Preparation of cellulose nanofibers aqueous suspensions}

The bleached cellulose was subjected to a TEMPO mediated oxidation (TEMPO/NaOCl/NaBr system) under alkaline conditions ( $\mathrm{pH} 10.5)$ for 30 min according to the method reported by Saito and Isogai (2004). The CNF suspensions were prepared by mechanical homogenization of the oxidized pulp (concentration of $4 \mathrm{wt} \%$ ). First, an Oster blender (Oster, BLSTSOG4661B, Mexico City, Mexico) was used for homogenization at a velocity of 15,000 rpm for $120 \mathrm{~min}$. Then, a second homogenization step was performed using an ultra-turrax (Janke \& Kunkel, TP18, Texas City, TX, USA) at 20,000 rpm for 5 min. Finally, a sonic treatment was conducted using an ultrasonic bath (Branson, $\mathrm{MH}$, Chicago, IL, USA) for $30 \mathrm{~min}$. The resulting product was a gel-like suspension.

\section{Preparation of nanocomposites (LMDPE-CNF) processed by thermocompression}

LMDPE was used as the matrix, and the agave cellulose nanofibers were used as reinforcements at concentrations of $0,1,3$, and $5 \mathrm{wt} \%$. Before processing, the agave nanofibers were dried for $24 \mathrm{~h}$ in an oven at $60{ }^{\circ} \mathrm{C}$ to eliminate moisture. Both components (LMDPE and dried CNF) were mixed manually in bags of plastic and then in a kitchen mixer (Black \& Decker SmartGrind) for 2 min. The resulting mixed samples (36 g) were put in a stainless-steel mold with dimensions of $170 \times 170 \times 1.4 \mathrm{~mm}$, applying the proportions shown in Table 1.

Table 1. Formulation of Samples with $0,1,3$, and 5 wt\% of CNF

\begin{tabular}{|c|c|c|}
\hline $\begin{array}{c}\text { Reinforcement } \\
(\mathrm{wt} \%)\end{array}$ & $\begin{array}{c}\text { LMDPE } \\
(\mathrm{g})\end{array}$ & $\begin{array}{c}\text { CNF } \\
(\mathrm{g})\end{array}$ \\
\hline 0 & 36 & 0 \\
\hline 1 & 35.64 & 0.36 \\
\hline 3 & 34.92 & 1.08 \\
\hline 5 & 34.2 & 1.8 \\
\hline
\end{tabular}

Torres-Rendón et al. (2019). “Agave nanocomposites,” BioResources 14(4), 9806-9825. 9809 
For the processing conditions, the plaques of the thermocompressor (constructed in Mexico) were first heated to $160{ }^{\circ} \mathrm{C}$. Then, a pressure of 25 bar was applied for $14 \mathrm{~min}$. Finally, the mold was cooled down with circulating water until it reached $50{ }^{\circ} \mathrm{C}$ (SilvaGuzmán et al. 2018).

Characterization of starting materials, nanocomposites, and bleached cellulose

The quantity of residual hemicelluloses in the pulp was calculated according to TAPPI um-233 (2001). The contents of the alpha, beta, and gamma celluloses in the pulp were obtained according to TAPPI T $203 \mathrm{~cm}-93$ (2009). Viscosimetry was performed to determine the degree of polymerization.

\section{Atomic force microscopy (AFM)}

Individual cellulose nanofibers were observed using an atomic force adsorption microscope (Park Systems, NX10, Suwon, South Korea). Before measurements, the samples were diluted in water until a ratio of 1:100 was reached, and then they were sonicated for $3 \mathrm{~h}$. Then, the samples were deposited on cleaved mica and dried at room temperature for $24 \mathrm{~h}$.

\section{Optical microscopy}

An optical microscope (OPTIKA Italy, B383PLi, Ponteranica, Italy) was used to: i) observe the morphological characteristics of the fibers before cooking and oxidative treatments, and ii) to observe delamination (fibrillation) of the cell wall induced by the mechanical treatments.

\section{Fourier transform infrared spectroscopy (FTIR)}

A spectrophotometer (Perkin-Elmer, Spectrum GX, Mexico City, Mexico) was used to perform FTIR spectroscopy. The attenuated total reflectance technique (ATR) was used, and all of the spectra were obtained by employing a resolution of $4 \mathrm{~cm}^{-1}$ in the frequency range from $4000 \mathrm{~cm}^{-1}$ to $700 \mathrm{~cm}^{-1}$.

\section{Lyophilization of $\mathrm{CNF}$}

Prior to lyophilization, the samples (water suspensions with nanofibers) were frozen using a temperature of $-21{ }^{\circ} \mathrm{C}$ for $24 \mathrm{~h}$. Then, the frozen samples were put in a lyophilizer (Labconco, FreeZone, Kansas City, USA) that worked with a vacuum of $70 \times$ $10^{3} \mathrm{Mbar}$ at $-47^{\circ} \mathrm{C}$ for $48 \mathrm{~h}$. The lyophilized samples were grounded until a fine powder was produced.

\section{Water absorption}

Water absorption was measured according to the standard ASTM D570-98 (1998). Samples with dimensions of $10 \times 50 \times 3 \mathrm{~mm}^{3}$ were submerged in distilled water at $25{ }^{\circ} \mathrm{C}$. Weight changes of the samples were monitored for several weeks. The diffusion coefficient (D) was calculated according to the method reported by Crank (1975), which is,

$$
\frac{M_{t}}{M_{\infty}}=1-\frac{8}{\pi^{2}} \sum_{n=0}^{\infty} \frac{1}{(2 n+1)^{2}} \exp \left(-D(2 n+1)^{2} \pi^{2} / l^{2}\right)
$$

where $M_{t}$ is the mass of absorbed water at time $t, M_{\infty}$ is the mass of absorbed water at the equilibrium and $l$ is the thickness of the samples. Five samples per type of material were measured. 


\section{Mechanical properties}

The tensile and flexural properties of the prepared nanocomposites were determined following the ASTM standards D638-14 (2004) and D790-17 (2017), respectively. The test samples for these three types of tests were prepared following these standards using a laser cutter (Guian, GN600LS, Shandong, China) along with the LaserWorkV6 software. The cutting speed was $5 \mathrm{~mm} / \mathrm{s}$ ( $50 \%$ of power laser). The samples were cut to achieve the dimensions determined by the D638-14 ASTM standard.

A universal testing machine (Instron, 3345, Barcelona, Spain) was utilized to perform the flexural and tensile tests. The cross-head speed was $1 \mathrm{~mm} / \mathrm{min}$ for both types of tests. In the case of the flexural tests, a span of $30 \mathrm{~mm}$ was used. A total of 8 samples were measured for each types of test.

\section{Scanning electron microscopy (SEM)}

The cross section of the fractured samples was analyzed with a high-resolution microscope (TESCAN, MIRA 3 LMU, Brno, Czech Republic). The fractured samples were coated with gold for $40 \mathrm{~s}$ in a sputtering Spi-module machine.

\section{RESULTS AND DISCUSSION}

\section{Acid Hydrolysis and Pulping Process}

Acid hydrolysis of agave fibers was performed to eliminate hemicelluloses and low molecular weight sugars. The resulting yield of cellulose was $40 \mathrm{wt} \%$. This value was similar to those reported in previous studies that used $2 \%$ of sulphuric acid for hydrolysis (Idarraga et al. 1999; Santiago et al. 2002; Saucedo-Luna et al. 2010; Abreu-Sherrer 2013). Based on these results, the low yield obtained in the present study could be attributed to the strong chemical attack that occurred during the hydrolysis and the cooking processes.

The Kappa number was determined, according to the standard TAPPI T 236-om99 (1999), to reveal the degree of delignification in the pulp. The resulting value was 6.97 , which was indicative of the strong delignification that occurred during the hydrolysis and the cooking process. This value was lower than those reported from the pulps of $A$. tequilana subjected to pulping processes, such as kraft (Kappa number of 28), soda (Kappa number of 60), and ethanol-soda (Kappa number of 33) (Idarraga et al. 1999).

From the four bleaching steps conducted in this work, cellulose yields of 95.6, 96, 97.7, and 98.2 wt\% were obtained, respectively. Moreover, elimination of hemicelluloses was also conducted to obtain a pulp with a higher content of $\alpha$-cellulose. The final cellulose content of the bleaching process was approximately $15 \mathrm{wt} \%$.

The values of the degree of polymerization were 252.2 (before bleaching) and 172.9 (after bleaching). The reduction of the degree of polymerization was due to the attacks that the cellulose chains suffered from the bleaching agents. The final content of $\alpha$-cellulose after bleaching was $89 \mathrm{wt} \%$.

\section{Characterization of CNF}

FTIR

The FTIR spectra of TEMPO-oxidized and non-TEMPO-oxidized samples (pulps) are shown in Fig. 1. The spectra of the pulp subjected to TEMPO oxidation have the characteristic bands of TEMPO-oxidized celluloses (Liang et al. 1959; Habibi et al. 2006; Ifuku et al. 2009). Notice that the band at $1730 \mathrm{~cm}^{-1}$ represents the protonated carboxyl groups generated by acidification of TEMPO-oxidized samples. It is important to mention 
that TEMPO-mediated oxidation replaces $\mathrm{OH}$ groups by carboxylic groups at carbon 6 (Isogai et al. 2011), and it is typically used as a chemical pretreatment for preparation of cellulose nanofibers (Saito et al. 2006; Ishii et al. 2011).

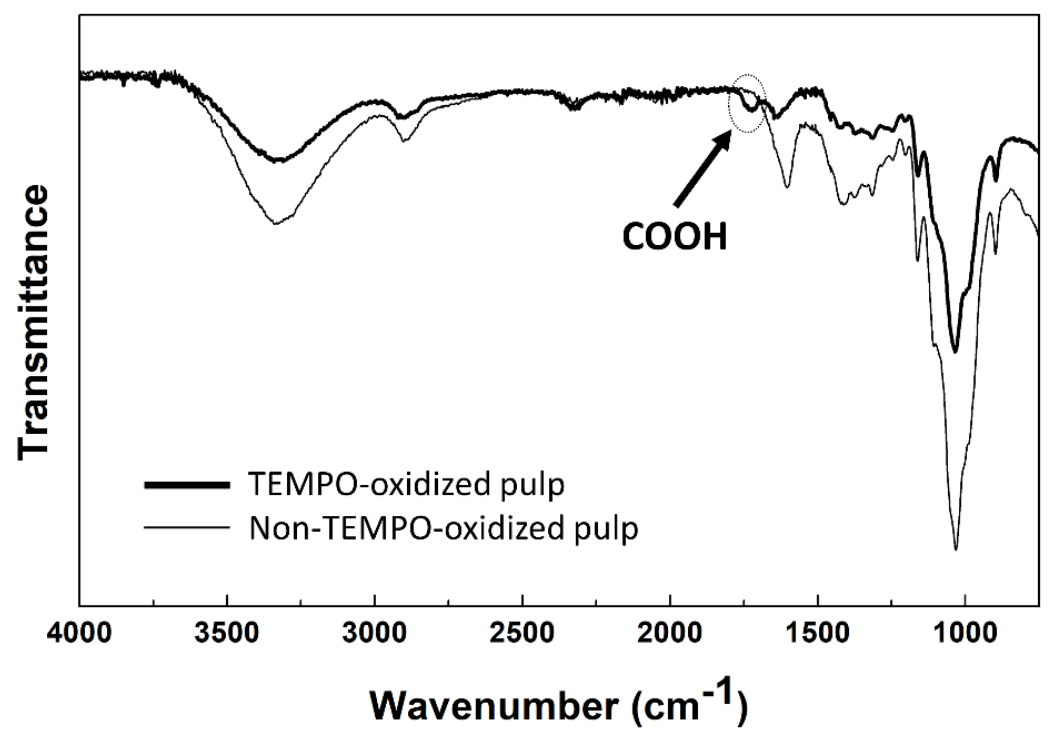

Fig. 1. FTIR spectra of non-TEMPO-oxidized and TEMPO-oxidized agave pulps

Atomic force microscopy (AFM)

AFM was utilized to confirm the presence of cellulose nanofibers in the prepared suspensions. Figure 2 shows an (a) AFM topographical image and (b) an illumination image of the obtained nanofibers. It was observed that the mechanical treatment was successful, but only on the TEMPO-oxidized pulps in which nanofibers of approximately $10 \mathrm{~nm}$ in diameter were obtained. The chemical treatment (TEMPO oxidation) favored nanofibrillation, as reported by Saito et al. (2006). The microfibers exhibited agglomerations due to the cellulose chains having an intermolecular hydrogen bonding and a strong hydrophilic interaction in between the cellulosic chains. These agglomerations were similar to those reported by Bhattacharya et al. (2008), who also reported whole microfibrillar bundles and individual nanofibers from bagasse sugarcane in AFM images. The mechanical friction in the pulp caused delamination of microfibrillar, which exposed internal areas of the cell wall and, therefore, increased the surface area.
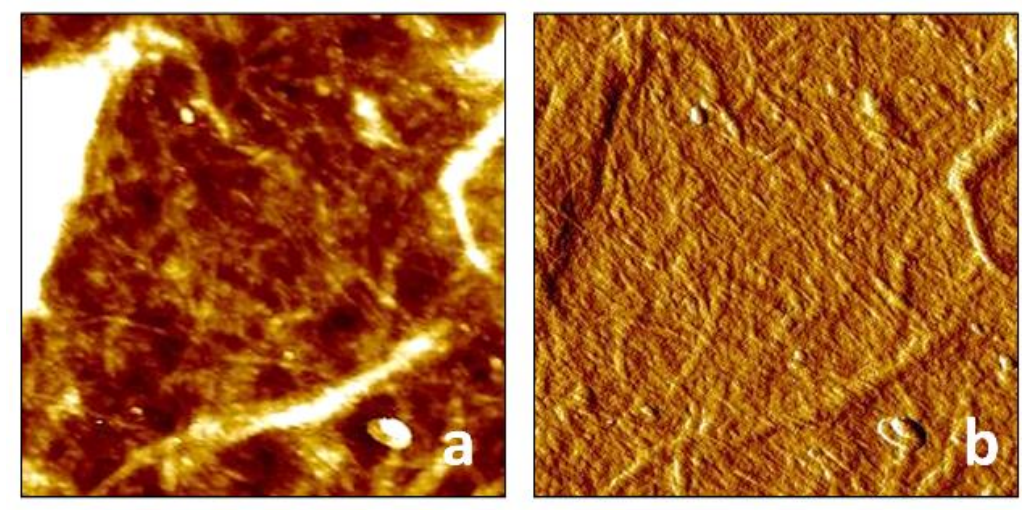

Fig. 2. (a) Topographical and (b) illumination AFM images of nanofibrils 


\section{Optical microscopy}

Figure 3a shows the optical microscopic images of the agave fibers. As can be seen, the cooking, bleaching, and TEMPO oxidation steps did not degrade the cell wall, as it remained intact even after the chemical processes. Figure $3 \mathrm{~b}$ presents both the effect of fibrillation (delamination of the cell wall) by the mechanical treatment and the sharp decrease in the length of the fibers. The mechanical friction processes produced many scattered nanofibers, as seen in the micrograph. The number of revolutions per minute, the consistency of the suspension, and the time of mechanical treatment influenced the quality of the nanofiber obtained. In addition, highly hydrated nanofibers were observed because, when the gel was formed, the suspension of the nanofibers reached about a $98 \%$ moisture content.
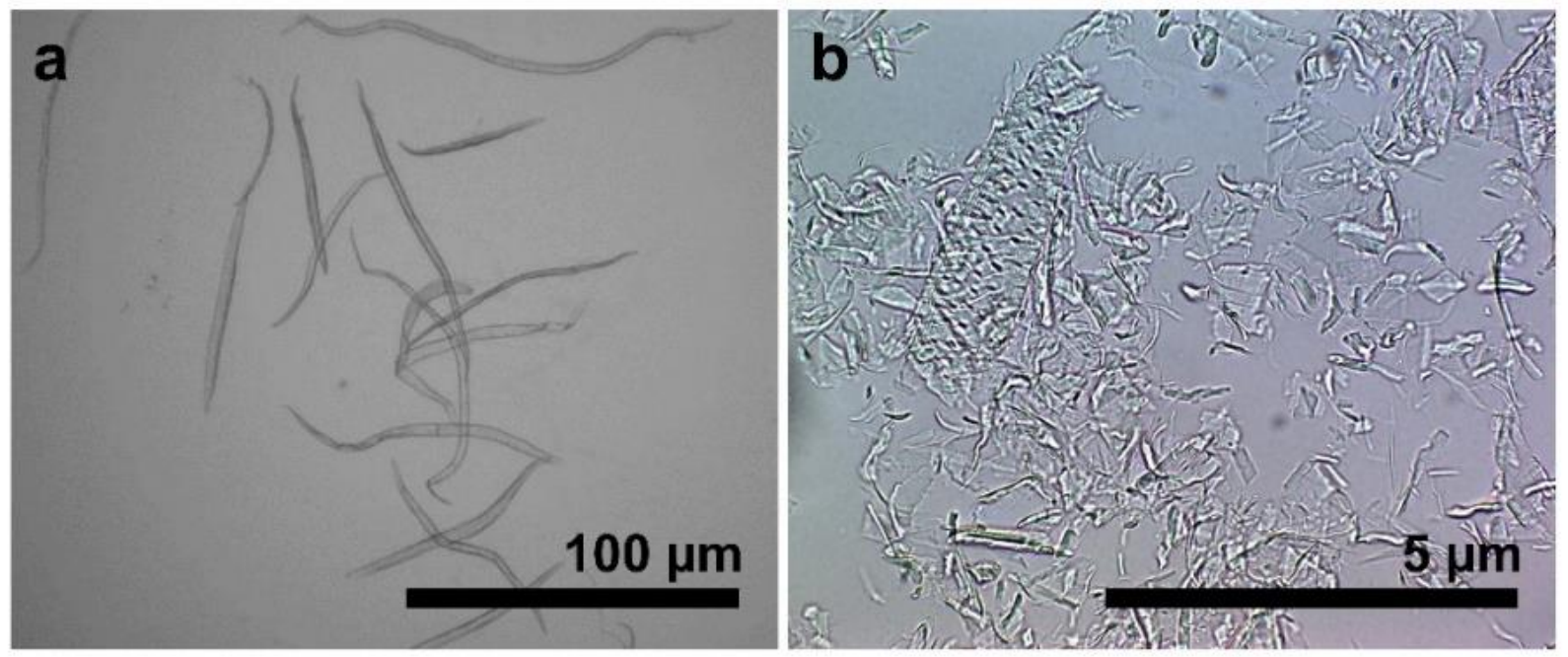

Fig. 3. Micrographs of (a) agave fibers before oxidation and mechanical treatment and (b) the resulted nanocellulose

\section{Characterization of Nanocomposites}

Water absorption study

The maximum water absorptions and the diffusion coefficient $(D)$ of all nanocomposites are shown in Table 2. The water absorptions were very low, even in $5 \mathrm{wt} \%$ CNF nanocomposites. This suggests that the hydrophobic matrix (LMDP) is the component that has more influence on the absorption of water. However, the absorption did increase with the incorporation of $\mathrm{CNF}$, which was expected because of the hydrophilic nature of the cellulose. The highest water absorption was achieved by the nanocomposite having $5 \mathrm{wt} \%$ of $\mathrm{CNF}(2.22 \pm 0.067)$.

Some studies have reported different amounts of water absorption for composites using natural fibers as reinforcements. For example, Becerra-Rodríguez et al. (2011) worked with low density polyethylene (LDPE)-agave fiber composites and observed a low water absorption. Frausto et al. (2015) reported water absorption values of up to $16 \%$ for LMDPE composites with $15 \mathrm{wt} \%$ of barley particles. In another study, Chen et al. (2016) reported water absorption values between 9 and $12 \%$ for composites of LDPE containing 4 to $6 \mathrm{wt} \%$ of bamboo particles. All these results indicated that the size of the material and their nature have a strong influence on the water absorption capacity. It is reported (Rowell et al. 2005; Beg and Pickering 2008a,b) that the behavior of the water absorption in polymer-based composites can be affected by three fundamental factors. First, the incorporated lignocellulosic material has a hygroscopic nature, considering that cellulose

Torres-Rendón et al. (2019). “Agave nanocomposites," BioResources 14(4), 9806-9825. 9813 
has hydroxyl groups $(\mathrm{OH})$ forming the chemical structure of the cellular wall of plant fibers. Secondly, there was a low quality of encapsulation of the incorporated particles in the thermoplastic matrix because, during the preparation of the composite, free pores or fault zones could be formed and help to facilitate the entry of water in the composite (Yamada et al. 2009). Thirdly, results were affected by the amount of lignocellulosic material that is added because a larger percentage of incorporated hydrophilic reinforcement into the polymer matrix correlates with a greater the water absorption (SilvaGuzmán et al. 2018). There seems to have been a lack of water absorption studies on nanocomposites having CNFs within hydrophobic matrices. In recent years, studies dealing with nanocomposites based on $\mathrm{CNF}$ and thermoplastic starch (as the matrix) have all reported water absorptions of approximately 50\% in $5 \mathrm{wt} \%$ CNF nanocomposites (Hietala et al. 2013; Nasri-Nasrabadi et al. 2014; Lomelí-Ramírez et al. 2018). In the case of Lomelí-Ramírez et al. (2018), CNF extracted from agave bagasse waste was used. This suggests that CNFs obtained from agave bagasse waste have practically the same effect on the absorption of water of composites, at least on those that have starch as a matrix, compared to other CNFs extracted from sources like softwood (Hietala et al. 2013) and rice straw (Nasri-Nasrabadi et al. 2014). It is important to mention that water absorption in composites depends on several factors, not only on the type of reinforcement. For example, it depends on the type of the matrix, the type of reinforcements, quantity of reinforcements, porosity, temperature, exposed areas of surfaces, among others (Springer 1981; Stamboulis et al. 2001; Deng et al. 2010). The maximum water absorption value found in this work was very low compared to those of starch-based nanocomposites having $5 \mathrm{wt} \%$ of CNF. This is believed to be due to the hydrophobic nature of the LDPE.

Figures 4 shows the water absorption kinetics of the nanocomposites. All nanocomposites have a similar kinetic behavior (high water uptake within the first $100 \mathrm{~h}$, and then reaching equilibrium at around $1400 \mathrm{~h}$, except for those having $1 \mathrm{wt} \% \mathrm{CNF}$, that reached equilibrium just after $100 \mathrm{~h}$ ).

Table 2. Maximum Water Absorptions and Diffusion Coefficients of Materials

\begin{tabular}{|c|c|c|}
\hline Material & $\begin{array}{c}\text { Water absorption } \\
(\%)\end{array}$ & $\begin{array}{c}\text { Diffusion } \\
\text { coefficient, } D, \\
\left(\mathrm{~m}^{2} / \mathrm{s}\right) 10^{-10}\end{array}$ \\
\hline LMDPE & 0 & 0 \\
\hline LMDPE (1 wt\% CNF) & $0.66 \pm 0.007$ & 2.083 \\
\hline LMDPE (3 wt\% CNF) & $1.92 \pm 0.053$ & 0.272 \\
\hline LMDPE (5 wt\% CNF) & $2.22 \pm 0.067$ & 0.3056 \\
\hline
\end{tabular}

The diffusion coefficients are displayed in Table $2(D)$. All values were in the range of those obtained from previous works dealing with composites having lignocellulosic reinforcements within hydrophobic matrices (Moscoso et al. 2012; Flores-Hernández et al. 2017), and also from studies about natural solids (Ochoa-Martínez and Ayala-Aponte 2005). Table 2 shows that the diffusion coefficient of nanocomposites having $1 \mathrm{wt} \%$ of $\mathrm{CNF}$ exhibited the highest value. In this case, the low quantity of CNF in the system (1 wt $\%$ ) could have led to a lack of enough contact points between the reinforcements, limiting the diffusion of water through the material. In the case of the nanocomposites with $3 \mathrm{wt} \%$ and $5 \mathrm{wt} \%$ of CNF, the diffusion coefficient is higher in the later, which can be attributed to the presence of more contact points between the nanofibers.

Torres-Rendón et al. (2019). "Agave nanocomposites," BioResources 14(4), 9806-9825. 9814 


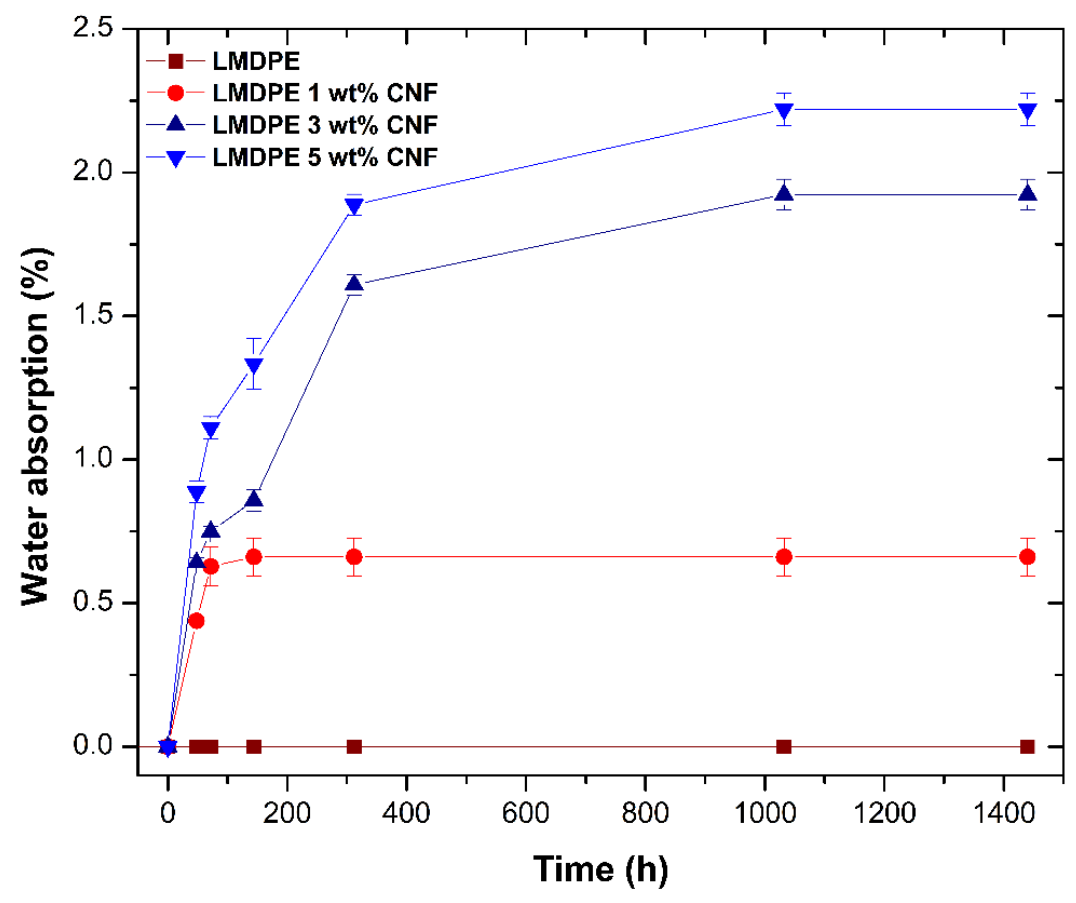

Fig. 4. Water absorption kinetics of the LMDPE nanocomposites

\section{Tensile properties}

Figure 5 shows the behavior of the tensile strength, Young's modulus, and the maximum elongation as functions of the amount of CNF in the nanocomposites. As can be seen in Figure 5a to b, the values of both tensile strength and Young's modulus remained practically the same compared to the matrix, suggesting that there was hardly any considerable effect on these properties with the incorporation of 1 and $3 \mathrm{wt} \%$ of CNF. However, both properties increased in nanocomposites containing $5 \mathrm{wt} \%$ of CNF, with tensile strength increasing by approximately $6 \%$ and Young's modulus increasing $29.4 \%$. These observations are similar to those reported earlier by other researchers (Oksman 1996; Solís and Lisperguer 2005; Leduc et al. 2008; Gaikwad and Mahanwar 2017). For example, Oksman (1996) and Solis and Lisperguer (2005) worked with LDPE and HDPE, respectively, and with wood particles as reinforcements. They concluded that the increase in tensile strength was not significant and that compatibilizing or coupling substances were required to achieve significant increases. Gaikwad and Mahanwar (2017), who worked with HDPE/henequen microfiber composites, observed tensile strength values of $20.3 \mathrm{MPa}$ and 21.1 MPa for pure HDPE and composites having $20 \mathrm{wt} \%$ microfibers, respectively. In that study, a maximum value of $22.4 \mathrm{MPa}$ of tensile strength was reported for composites with $5 \mathrm{wt} \%$ of microfibers. In another study, Leduc et al. (2008) studied the effect of fiber content and the amount of coupling agent maleic anhydride (MAPE) on the mechanical properties of LDPE/raw A. tequilana fibers composites. They observed that Young's and flexural moduli increased with fiber content. However, they also observed a decrease in impact strength with an increase in fiber content. The addition of MAPE increased the effect to an optimum content between 2 and $5 \%$ on a fiber weight basis.

In another study, polyethylene-based composites with various concentrations of raw agave fibers $(5,10$, and $15 \mathrm{wt} \%)$, processed by rotomolding, decreased in tensile strength with increasing amounts of fibers (López-Bañuelos et al. 2012). This has been attributed to both the difficulty of obtaining a homogeneous mixture with an increase of fibers and the resulting agglomeration of the fibers that occurs inside the rotating mold. 
Furthermore, values of tensile strength and Young's modulus of composites obtained in the present study, containing $5 \mathrm{wt} \%$ of $\mathrm{CNF}$, were comparable with those reported for composites containing $20 \mathrm{wt} \%$ and $30 \mathrm{wt} \%$ of fibers in a polyethylene matrix (Cisneros-López et al. 2017).

In the case of the elongation at break (maximum deformation), Fig. 5c demonstrates that a decrease in its values was correlated with an increase in CNF content. Such a decrease in elongation can be attributed to the low elasticity of the fibers, as reported earlier by Cisneros-López et al. (2017). It has also been reported that depending on the type of reinforcement, fibers do not contribute to elongation (López-Bañuelos et al. 2012).
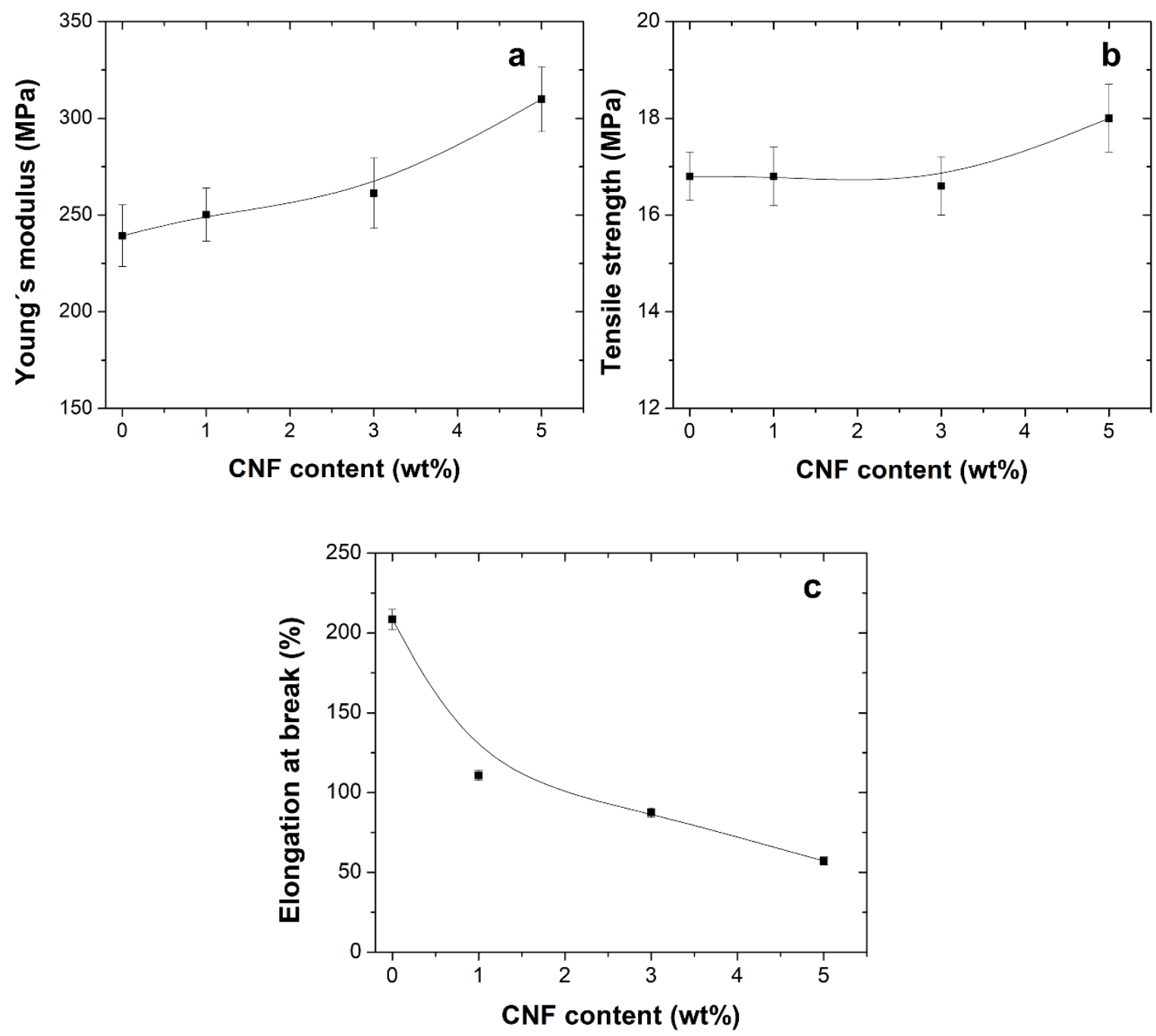

Fig. 5. Plots of (a) tensile strength, (b) Young's modulus, and (c) maximum elongation as functions of the amount of CNF in the nanocomposites

\section{Flexural properties}

Table 3 shows the values of the flexural strength and flexural modulus, as well as the maximum deflection of the LMDPE/CNF nanocomposites. As noted, the maximum value was at $5 \%$ deflection, according to the norm, even when higher deflections were reported. Also, depending on the number of incorporated nanofibers, a noticeable effect on the deflection was observed. However, a slight decrease in the average value of the deflection was correlated with an increasing number of nanofibers added. Table 3 also 
shows (i) a reduction of approximately $8 \%$ of flexural strength and flexural modulus with the addition of $1 \mathrm{wt} \% \mathrm{CNF}$ and (ii) an increase in the average value of the flexural modulus with 3 and $5 \mathrm{wt} \%$ of CNF. Interestingly, the values of flexural modulus obtained in the present study with $5 \mathrm{wt} \%$ of CNF were comparable with those obtained by Tronc et al. (2007) with HDPE-50 wt\% blue agave fiber composites (900 MPa). Similarly, the flexural modulus value of LDPE composites, obtained via thermocompression, containing $30 \mathrm{wt} \%$ of raw agave fiber, reported by Cisneros-López et al. (2017), could be achieved with just $5 \mathrm{wt} \%$ of nanofibers of blue agave in the present study.

Table 3. Mechanical Flexural Properties of the LMDPE Matrix Nanocomposites

\begin{tabular}{|c|c|c|c|}
\hline Material & $\begin{array}{c}\text { Flexural } \\
\text { Resistance } \\
(\mathrm{MPa})\end{array}$ & $\begin{array}{c}\text { Maximum } \\
\text { Deflection } \\
(\mathrm{mm} / \mathrm{mm})\end{array}$ & $\begin{array}{c}\text { Flexural } \\
\text { Modulus } \\
(\mathrm{MPa})\end{array}$ \\
\hline LMDPE & $23.55 \pm 0.91$ & $6.80 \pm 0.21$ & $821.1 \pm 51.6$ \\
\hline LMDPE (1 wt\% CNF) & $21.53 \pm 0.61$ & $6.64 \pm 0.19$ & $758.6 \pm 20.9$ \\
\hline LMDPE (3 wt\% CNF) & $24.13 \pm 0.85$ & $6.61 \pm 0.31$ & $888.4 \pm 45.4$ \\
\hline LMDPE (5 wt\% CNF) & $25.62 \pm 0.74$ & $6.55 \pm 0.13$ & $893.4 \pm 41.2$ \\
\hline
\end{tabular}

Figure 6 shows the flexural strength as a function of the amount of CNF present in the materials. The flexural strength decreased with the addition of $1 \mathrm{wt} \% \mathrm{CNF}$, while it increased when the addition of the fiber was increased to 3 and $5 \mathrm{wt} \% \mathrm{CNF}$. The values of flexural strength (FS) (19.5 MPa) and flexural modulus (FM) (700 MPa) observed by Kiziltas et al. (2016) in HDPE-10 wt\% of nanofibers composites processed by an injection molding process were lower compared to the values obtained in the present study with 5 wt\% CNF (FS: 25.6 MPa; FM: 893.4 MPa). Higher values of the observed FS and FM values in the present study can be attributed to a relatively better interaction between the nanofibers and the matrix. On the contrary, the lower values of the FS and the FM with a higher amount of nanofibers observed by Kiziltas et al. (2016) can be attributed to the limited interaction between the matrix (HDPE) and the nanofibers, which results in an increase in free volume and thus a decrease in the observed properties (Nakagaito et al. 2011; Kumode et al. 2017).

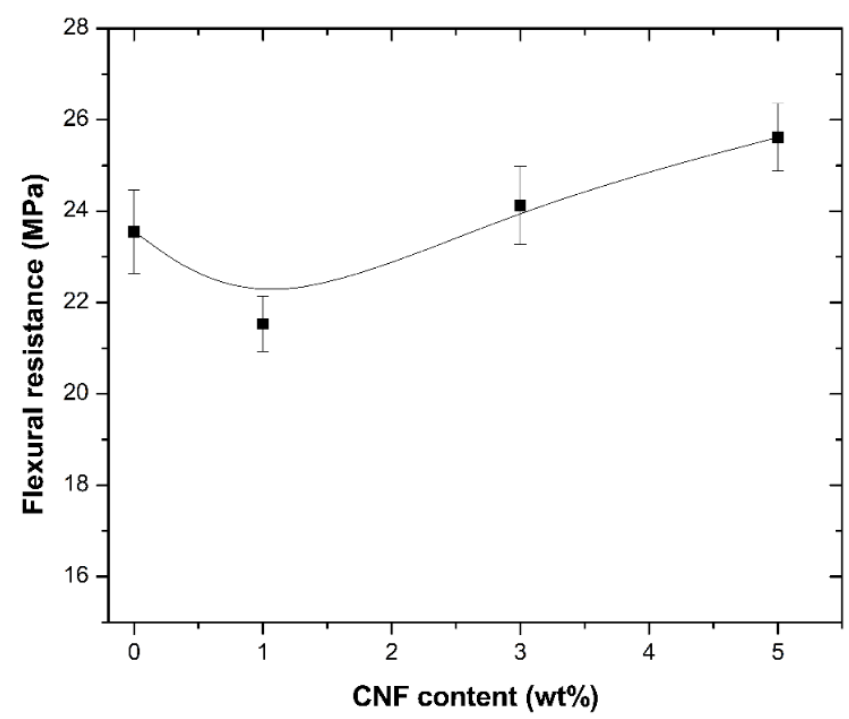

Fig. 6. Resistance to bending as a function of the CNF content 


\section{Microscopy Studies of Nanocomposites}

Optical microscopy

Figure 7a shows a macrophotograph of the LMDPE matrix placed on a glass plate. Figure $7 \mathrm{~b}$ to $\mathrm{d}$ are the macrophotographs of the LMDPE/CNF nanocomposites containing 1,3 , and $5 \mathrm{wt} \%$ of nanofibers, respectively, each of which was placed on a glass plate. Figure 7 e to h show optical micrographs of these at $40 \times$ magnification. In these macro and microphotographs, a good dispersion of the nanofibers in the matrix was evident, with a dark color becoming more intense with an increase in the number of nanofibers in the matrix.

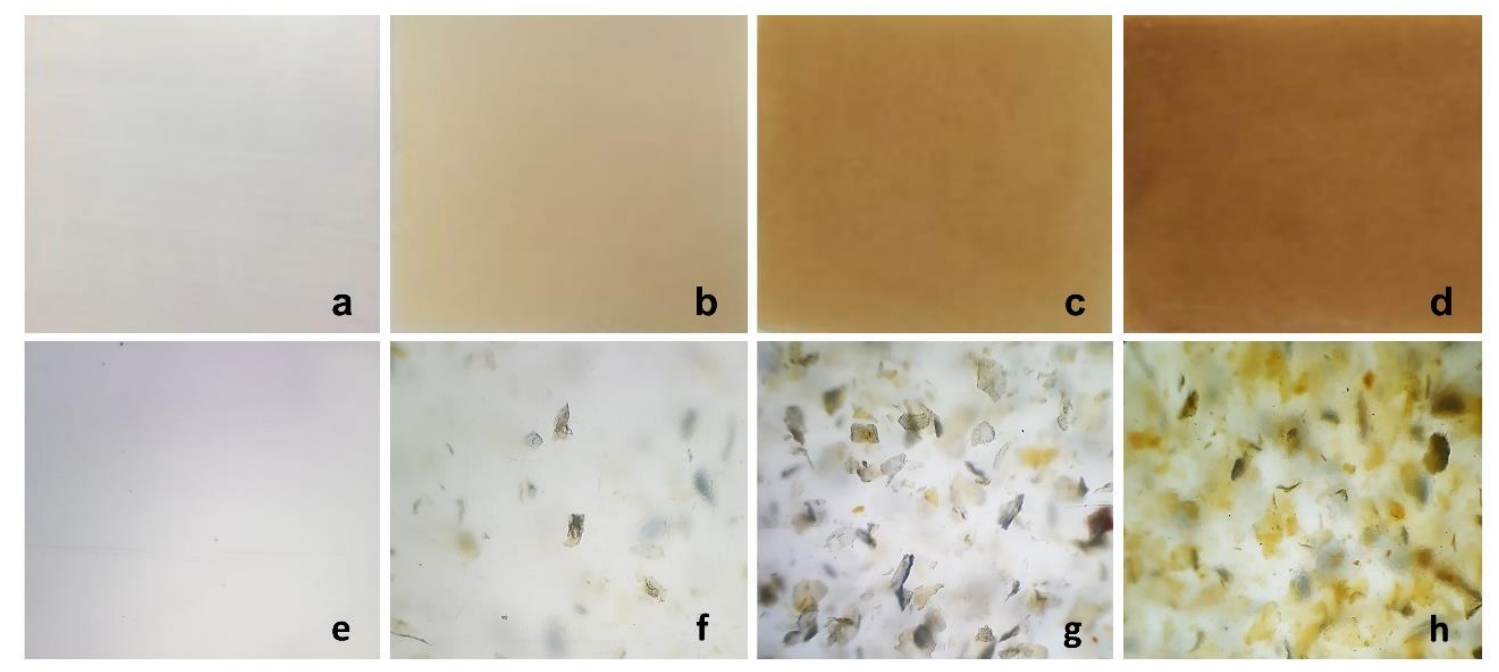

Fig. 7. Photos and micrographs of the LMDPE/CNF nanocomposites. Macrophotographs from (a) to (d) show LMDPE/CNF composites having $0 \mathrm{wt} \%, 1 \mathrm{wt} \%, 3 \mathrm{wt} \%$, and $5 \mathrm{wt} \%$ of CNF, respectively. Optical micrographs of (e) $0 \mathrm{wt} \%$, (f) $1 \mathrm{wt} \%$, (g) $3 \mathrm{wt} \%$, and (h) $5 \mathrm{wt} \%$ CNF were taken at a magnification of $40 x$.

Figure 8 shows a micrograph of the LMDPE/CNF nanocomposites, revealing the aggregates formed by the cellulose nanofibers. As can be seen, most of these aggregates had a flat layer shape. These layers were probably formed by the removal of water during lyophilization. Considering that the adopted procedure in this study to prepare the LMDPE/CNF nanocomposites involved the drying of nanofibers suspensions, it was not possible to avoid the formation of aggregates.

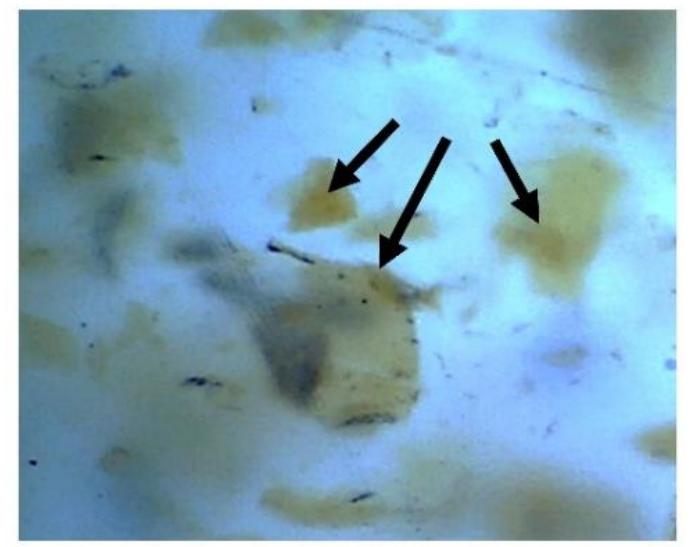

Fig. 8. Photos of the LMDPE-CNF nanocomposites showing aggregates of CNF in the matrix 


\section{Scanning electron microscopy}

Figure 9a to d shows SEM micrographs of the fractured surface of tensile tested samples with Fig. 10a revealing the texture of the matrix. Figure $9 \mathrm{~b}$ to $\mathrm{d}$ correspond to the nanocomposites containing 1, 3, and $5 \mathrm{wt} \%$ of CNF, respectively. All of the images show circular granules of CNF that were approximately 1 to $3 \mu \mathrm{m}$ in diameter. However, the thickness could not be determined.
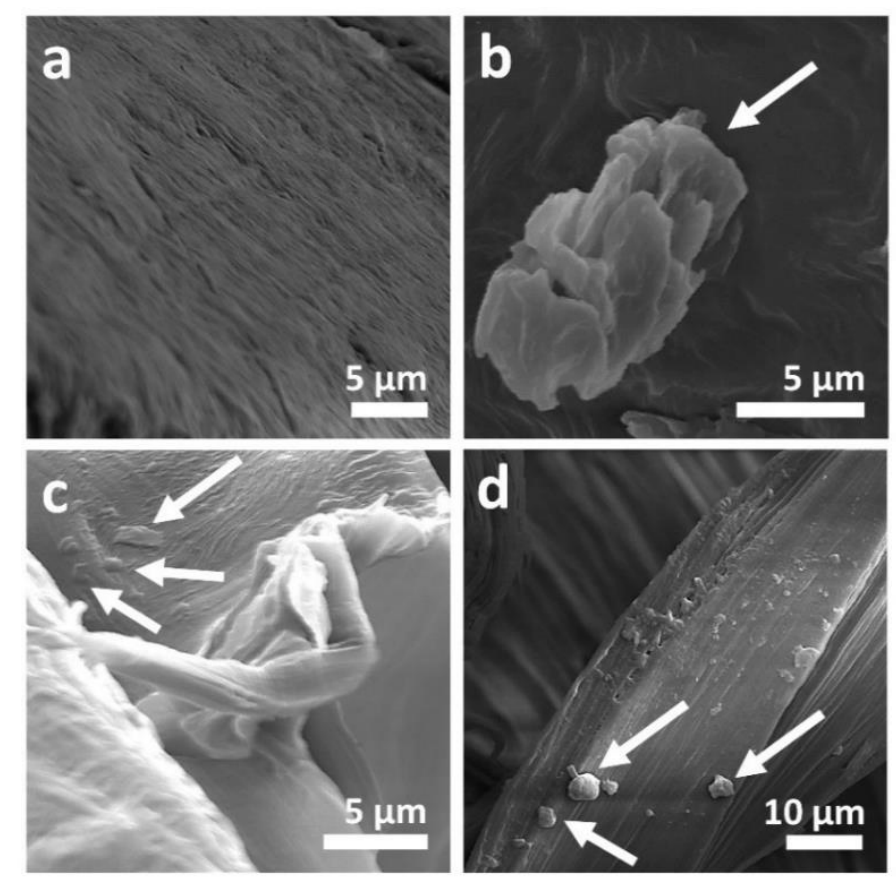

Fig. 9. SEM images of the LMDPE matrix and LMDPE/CNF nanocomposites: (a) Pristine LMDPE, (b) Nanocomposites with 1 wt\% CNF, (c) Nanocomposites with 3 wt\% CNF, and (d) Nanocomposites with 5 wt\% CNF

One of the most important challenges related to the use of nanocelluloses, in the form of nanofibers or nanocrystals, is their drying because of their hydrophilic nature, which tends to cause the formation of agglomerations (Peng et al. 2012). Hydrogen bonds can be generated during their drying, leading to their irreversible agglomeration known as hornification (Eyholzer et al. 2010). This process changes both the size of the nanocellulosic materials and their unique characteristics.

\section{CONCLUSIONS}

1. A yield of $40 \mathrm{wt} \%$ of cellulose was obtained by the pre-treatment and pulping of the agave bagasse.

2. A yield of about $15 \mathrm{wt} \%$ of bleached pulp was obtained through processing agave bagasse.

3. Nanofibers could be obtained by applying mechanical treatment on TEMPO-oxidized pulps from agave bagasse waste, as observed in the AFM studies.

4. All of these treatments (cooking and bleaching of pulp followed by TEMPO treatments) did not degrade the cell walls of the fibers, as observed in the optical 
microscopy studies.

5. Water absorption was very low for all nanocomposites prepared in this work.

6. An increase in both tensile strength and Young's modulus of nanocomposites containing $5 \mathrm{wt} \% \mathrm{CNF}$ was observed, compared to pristine LMDPE. On the contrary, elongation of nanocomposites decreased with an increasing CNF content.

7. Flexural strength and flexural modulus of the nanocomposites decreased about $8 \%$ with the addition of $1 \mathrm{wt} \% \mathrm{CNF}$, while both of these properties increased for nanocomposites containing 3 and $5 \mathrm{wt} \% \mathrm{CNF}$. These results can be attributed to a favorable dispersion of nanofibers in nanocomposites with 3 and $5 \mathrm{wt} \% \mathrm{CNF}$. This suggests that the nanofibers functioned as the load carriers rather than as reinforcements, particularly in the nanocomposites with $1 \mathrm{wt} \% \mathrm{CNF}$.

8. One of the challenges for researchers working in the area of material science is to develop suitable drying methods to prevent agglomeration of nanocelluloses.

\section{ACKNOWLEDGEMENTS}

The authors express their gratitude to CONACYT for the scholarship assigned to Mario Edgar Valdez-Fausto. Furthermore, the authors thank the Mexican Secretariat of Public Education for its support to the project: "Development and innovation in nanomaterials and nanocomposites, from the International Thematic Network, call 2015." Also, the authors thank the company Mundo Agave in Jalisco, Mexico, for providing fibers of the Weber blue variety of A. tequilana. Last, one of the authors (Dr. KGS) acknowledges the Poornaprajna Institute of Scientific Research (PPISR) in Bangalore for their encouragement of this work.

Declarations of interest/conflicts of interest: On behalf of all the authors, it is declared that there are no financial and personal relationships with other people or organizations through the following: employment, consultancies, stock ownership, honoraria, paid expert testimony, patent applications/registrations, and grants or other funding, which would inappropriately influence this study.

\section{REFERENCES CITED}

Abreu-Sherrer, J. S. (2013). Aprovechamiento de Bagazo de Agave Tequilana Weber Para La Producción de Bio-Hidrógeno, Master's Thesis, Instituto Potosino de Investigación Científica y Tecnológica, San Luis Potosí, Mexico.

ASTM D570-98 (1998). "Standard test method for water absorption of plastics," ASTM, New York, NY.

ASTM D638-14 (2004). "Standard test method for tensile properties of plastics," ASTM, New York, NY.

ASTM D790-17 (2017). "Standard test methods for flexural properties of unreinforced and reinforced plastics and electrical insulating materials," ASTM, New York, NY.

Becerra-Rodríguez, M. B., Shastri, R., Zitzumbo-Guzmán, R., and García-Alcaraz, J. L. (2011). "Compuesto de polietileno de baja densidad y fibra de Agave tequilana," Cultural Científica y Tecnológica 45(8), 71-78. Retrieved from 
http://erevistas.uacj.mx/ojs/index.php/culcyt/article/view/197

Beg, M. D. H., and Pickering, K. L. (2008a). "Reprocessing of wood fibre reinforced polypropylene composites. Part I: Effects on physical and mechanical properties," Compos. Part A-Appl. S. 39(7), 1091-1100. DOI: 10.1016/j.compositesa.2008.04.013

Beg, M. D. H., and Pickering, K. L. (2008b). "Reprocessing of wood fibre reinforced polypropylene composites. Part II: Hygrothermal ageing and its effects," Compos. Part A-Appl. S. 39(9), 1565-1571. DOI: 10.1016/j.compositesa.2008.06.002

Bhattacharya, D., Germinario, L. T., and Winter, W. T. (2008). "Isolation, preparation and characterization of cellulose microfibers obtained from bagasse," Carbohyd. Polym. 73(3), 371-377. DOI: 10.1016/j.carbpol.2007.12.005

Cai, Z. Y., and Niska, K. O. (2011). "Nanocelluloses: Potential materials for advanced forest products," in: Proceedings of Nanotechnology in Wood Composites Symposium, Madison, WI.

Cao, Y., Chan, F., Chui, Y. H., and Xiao, H. (2012). "Characterization of flax fibres modified by alkaline, enzyme, and steam-heat treatments," BioResources 7(3), 41094121. DOI: 10.15376/biores.7.3.4109-4121

Chen, Q., Zhang, R., Wang, Y., Wen, X., and Qin, D. (2016). "The effect of bamboo charcoal on water absorption, contact angle, and the physical-mechanical properties of bamboo/low-density polyethylene composites," BioResources 11(4), 9986-10001. DOI: 10.15376/biores.11.4.9986-10001

Cisneros-López, E. O., Anzaldo, J., Fuentes-Talavera, F. J., González-Núñez, R., Robledo-Ortíz, J. R., and Rodrigue, D. (2017). "Effect of agave fiber surface treatment on the properties of polyethylene composites produced by dry-blending and compression molding," Polym. Composite. 38(1), 96-104. DOI: $10.1002 /$ pc. 23564

Crank, J. (1975). The Mathematics of Diffusion. Oxford University Press, London, United Kingdom.

Tequila Regulatory Counsel. (2017). "Regularization of Tequila," (https://www.crt.org.mx), Accessed December 2017.

Darabi, P., Gril, J., Thevenon, M. F., Karimi, A. N., and Azadfalah, M. (2012). "Evaluation of high-density polyethylene composite filled with bagasse after accelerated weathering followed by biodegradation," BioResources 7(4), 5258-5267. DOI: $10.15376 /$ biores.7.4.5258-5267

Deng, H., Reynolds, C. T., Cabrera, N. O., Barkoula, N. M., Alcock, B., and Peijs, T. (2010). "The water absorption behaviour of all-polypropylene composites and its effect on mechanical properties," Compos. B Eng. 41(4), 268-275. DOI: 10.1016/j.compositesb.2010.02.007

Dufresne, A. (2010). "Processing of polymer nanocomposites reinforced with polysaccharide nanocrystals," Molecules 15(6), 4111-4128. DOI: 10.3390/molecules 15064111

Eyholzer, C., Bordeanu, N., Lopez-Suevos, F., Rentsch, D., Zimmermann, T., and Oksman, K. (2010). "Preparation and characterization of water-redispersible nanofibrillated cellulose in powder form," Cellulose 17(1), 19-30. DOI: 10.1007/s10570-009-9372-3

Flores-Hernández, M. A., Torres-Rendón, J. G., Jiménez-Amezcua, R. M., LomelíRamírez, M. G., Fuentes-Talavera, F. J., Silva-Guzmán, J. A., and García Enriquez, S. (2017). "Studies on mechanical performance of wood-plastic composites: polystyrene-Eucaliyptus globulus Labill," BioResources 12(3), 6392-6404. DOI: 10.15376/biores.12.3.6392-6404 
Frausto-Gutiérrez, O., Román-Gutiérrez, A. D., Jiménez-Amezcua, R. M., and LomelíRamírez, M. G. (2015). "Caracterización de materiales termoplásticos reforzados con partículas de cebada," in: Proceedings of Congresso Internacional Investigación Academica 2015, Celaya, Mexico, pp. 1790-1795.

Gaikwad, P., and Mahanwar, P. (2017). "Studies in effect of synthetic and natural microfibers on properties of high-density polyethylene reinforced composite," Polym.-Plast. Technol 56(2), 1525-6111. DOI: 10.1080/03602559.2016.1185618

Habibi, Y., Chanzy, H., and Vignon, M. R. (2006). "TEMPO-mediated surface oxidation of cellulose whiskers," Cellulose 13(6), 679-687. DOI: 10.1007/s10570-006-9075-y

Hietala, M., Mathew, A. P., and Oksman, K. (2013). "Bionanocomposites of thermoplastic starch and cellulose nanofibers manufactured using twin-screw extrusion,” Eur. Polym. J. 49(4), 950-956. DOI: 10.1016/j.eurpolymj.2012.10.016

Idarraga, G., Ramos, J., Zuñiga, V., Sahin, T., and Young, R. A. (1999). "Pulp and paper from blue agave waste from tequila production," J. Agr. Food Chem. 47(10), 44504455. DOI: 10.1021/jf990045n

Ifuku, S., Tsuji, M., Morimoto, M., Saimoto, H., and Yano, H. (2009). "Synthesis of silver nanoparticles templated by TEMPO-mediated oxidized bacterial cellulose nanofibers," Biomacromolecules 10(9), 2714-2717. DOI: 10.1021/bm9006979

Ishii, D., Saito, T., and Isogai, A. (2011). "Viscoelastic evaluation of average length of cellulose nanofibers prepared by TEMPO-mediated oxidation," Biomacromolecules 12(3), 548-550. DOI: $10.1021 / \mathrm{bm} 1013876$

Isogai, A., Saito, T., and Fukuzumi, H. (2011). "TEMPO-oxidized cellulose nanofibers," Nanoscale 3(1), 71-85. DOI: 10.1039/c0nr00583e

Johnson, R. K. (2010). TEMPO-Oxidized Nanocelluloses: Surface Modification and Use as Additives in Cellulosic Nanocomposites, Ph.D. Dissertation, Virginia Polytechnic \& State University, Blacksburg, VA.

Kalia, S., Dufresne, A., Cherian, B. M., Kaith, B. S., Avérous, L., Njuguna, J., and Nassiopoulos, E. (2011). "Cellulose-based bio- and nanocomposites: A review," Int. J. Polym. Sci. 2011(8), 1-35. DOI: 10.1155/2011/837875

Kalia, S., Kaith, B. S., and Kaur, I. (2011). Cellulose Fibers: Bio- and Nano-Polymer Composites: Green Chemistry and Technology, Springer, Verlag Berlin Heidelberg. DOI: 10.1007/978-3-642-17370-7

Khalil, H. P. S., Bhat, A. H., and Yusra, A. F. (2012). "Green composites from sustainable cellulose nanofibrils: A review," Carbohyd. Polym. 87(2), 963-979. DOI: 10.1016/j.carbpol.2011.08.078

Kiziltas, A., Nazari, B., Kiziltas, E. E., Gardner, D. J. S., Han, Y., and Rushing, T. S. (2016). "Cellulose nanofiber-polyethylene nanocomposites modified by polyvinyl alcohol,” J. Appl. Polym. Sci. 133(6), 1-8. DOI: 10.1002/app.42933

Klemm, D., Kramer, F., Moritz, S., Lindström, T., Ankerfors, M., Gray, D., and Dorris A. (2011). "Nanocelluloses: A new family of nature-based materials," Angew. Chem. Int. Edit. 50(24), 5438-5466. DOI: 10.1002/anie.201001273

Kumode, M. M. N., Muniz, G. I. B., Magalhães, W. L. E., and Satyanarayana, K. G. (2017). "Microfibrillated nanocellulose from balsa tree as potencial reinforcement in the preparation of a 'green' composites with castor seed cake," J. Clean. Prod. 149, 1157-1163. DOI: 10.1016/j.jclepro.2017.02.083

Leduc, S., Ureña, G. J. R., González-Núñez, R., Quirarte, J. R., Riedl, B., Rodrigue, D. (2008). "LDPE/agave fibre composites: Effect of coupling agent and weld line on mechanical and morphological properties," Polym. Polym. Compos. 16(2), 115-123. DOI: $10.1177 / 096739110801600204$ 
Lee, K. Y., Aitomäki, Y., Berglund, L. A., Oksman, K., and Bismarck, A. (2014). "On the use of nanocellulose as reinforcement in polymer matrix composites," Compos. Sci. Technol. 105, 15-27. DOI: 10.1016/j.compscitech.2014.08.032

Liang, C. Y., and Marchessault, R. H. (1959). "Infrared spectra of crystalline polysaccharides. II. Native celluloses in the region from 640 to $1700 \mathrm{~cm} .^{-1}, " J$. Polym. Sci. 39, 269-278. DOI: 10.1002/pol.1959.1203913521

Lomelí-Ramírez, M. G., Valdez-Fausto, E. M., Rentería-Urquiza, M., Jiménez-Amezcua, R. M., Anzaldo Hernández, J., Torres-Rendon, J. G., García Enriquez, S. (2018). "Study of green nanocomposites based on corn starch and cellulose nanofibrils from Agave tequilana Weber," Carbohyd. Polym. 201, 9-19. DOI:

10.1016/j.carbpol.2018.08.045

López-Bañuelos, R. H., Moscoso, F. J., Ortega-Gudiño, P., Mendizabal, E., Rodrigue, D., and González-Núñez R. (2012). "Rotational molding of polyethylene composites based on agave fibers," Polym. Eng. Sci. 52(12), 2-9. DOI:10.1002/pen.23168

Mariano, M., El Kissi, N., and Dufresne, A. (2014). "Cellulose nanocrystals and related nanocomposites: Review of some properties and challenges," J. Polym. Sci. Pol. Phys. 52(12), 791-806. DOI: 10.1002/polb.23490

Moscoso, F. J., Martínez, L., Canche, G., Rodrigue, D., and González-Núñez, R. (2012). "Morphology and properties of polystyrene/agave fiber composites and foams," $J$. Appl. Polym. Sci. 127(1), 599-606. DOI: 10.1002/app.37843

Nakagaito, A. N., Takagi, H., and Pandey, J. K. (2011). "The processing and mechanical performance of cellulose nanofiber-based composites," Int. J. Ocean Syst. Eng. 1(4), 180-184. DOI: 10.5574/IJOSE.2011.1.4.180

Nasri-Nasrabadi, B., Behzad, T., and Bagheri, R. (2014). "Preparation and characterization of cellulose nanofiber reinforced thermoplastic starch composites," Fibers Polym. 15(2), 347-354. DOI: 10.1007/s12221-014-0347-0

Ochoa-Martínez, C. I., and Ayala-Aponte, A. (2005). "Mathematical models of mass transfer in osmotic dehydration. CYTA-J. Food 4(5), 330-342. DOI: $10.1080 / 11358120509487660$

Oksman, K. (1996). "Improved interaction between wood and synthetic polymers in wood / polymer composites," Wood Sci. Technol. 30(3), 197-205. DOI: 10.1007/BF00231633

Peng, Y., Gardner, D. J., and Han, Y. (2012). "Drying cellulose nanofibrils: In search of a suitable method," Cellulose 19(1), 91-102. DOI: 10.1007/s10570-011-9630-z

Pérez-Fonseca, A. A., Arellano, M., Rodrigue, D., González-Núñez, R., and RobledoOrtíz, J. R. (2016). "Effect of coupling agent content and water absorption on the mechanical properties of coir-agave fibers reinforced polyethylene hybrid composites," Polym. Composite. 37(10), 3015-3024. DOI: 10.1002/pc.23498

Rowell, R., Pettersen, R., and Tshabalala, M. (2005). "Cell wall chemistry," in: Handbook of Wood Chemistry and Wood Composites, R. M. Rowell (ed.), CRC Press, Boca Raton, FL. DOI: 10.1201/b12487

Saito, T., and Isogai, A. (2004). "TEMPO-mediated oxidation of native cellulose. The effect of oxidation conditions on chemical and crystal structures of the waterinsoluble fractions," Biomacromolecules 5(5), 1983-1989. DOI: 10.1021/bm0497769

Saito, T., Nishiyama, Y., Putaux, J. L., Vignon, M., and Isogai, A. (2006). "Homogeneous suspensions of individualized microfibrils from TEMPO-catalyzed oxidation of native cellulose," Biomacromolecules 7(6), 1687-1691. DOI: $10.1021 / \mathrm{bm} 060154 \mathrm{~s}$

Santiago, D., Rodríguez, N., and Mogollón, G. (2002). "Potencial papelero de la fibra de 
sisal (Agave sisalana)," Revista Forestal Venezolana 46(2), 19-27. Retrieved from http://www.sidalc.net/cgi-

bin/wxis.exe/?IsisScript=SERAMZ.xis\&method=post\&formato=2\&cantidad=1\&exp resion $=\mathrm{mfn}=033026$

Satyanarayana, K. G., Anupama, R., Prasad, V. S., and Magalhães, W. L. E. (2017).

"Preparation, characterization, and applications of nanomaterials (cellulose, lignin, and silica) from renewable (lignocellulosic) resources," in: Handbook of Composites

from Renewable Materials, V. K. Thakur, M. K. Thakur, and M. R, Kessler (eds.), Scrivener Publishing, Beverly, MA. DOI: 10.1002/9781119441632

Satyanarayana, K. G., Flores-Sahagun, T. H. S., Dos Santos, L. P., Dos Santos, J., Mazzaro, I., and Mikowski, A. (2013). "Characterization of blue agave bagasse fibers of Mexico," Compos. Part A-Appl. S. 45, 153-161. DOI:

10.1016/j.compositesa.2012.09.001

Satyanarayana, K. G., Ramos, L. P., and Wypych, F. (2004). "Development of new materials based on agro and industrial wastes towards ecofriendly society," in:

Biotechnol Energy Management Vol. II, T. K. Ghosh, T. Chakrabarti, and G. Tripathi (eds.), APH Publishing Corporation, New Delhi, India.

Saucedo-Luna, J., Castro-Montoya, A. J., Rico, J. L., and Campos-García, J. (2010). "Optimization of acid hydrolysis bagasse from Agave tequilana weber," Rev. Mex. Ing. Quím. 9(1), 91-97. Retrieved from http://www.redalyc.org/articulo.oa?id=62016243011

Silva-Guzmán, J. A., Anda, R. R., Fuentes-Talavera, F. J., Manríquez-González, R., and Lomelí-Ramírez, M. G. (2018). "Properties of thermoplastic corn starch based green composites reinforced with barley (Hordeum vulgare L.) straw particles obtained by thermal compression," Fibers Polym. 19(9), 1970-1979. DOI: 10.1007/s12221-0188023-4

Solís, M. E., and Lisperguer, J. H. (2005). "Resistencia al impacto y a la tracción de materiales compuestos plástico-madera," Información Tecnológica 16(6), 21-25. DOI: $10.4067 / \mathrm{S} 0718-07642005000600004$

Springer, G. S. (1981). Environmental Effects on Composite Materials, University of California, CA.

Stamboulis, A., Baillie, C. A., Peijs, T. (2001). "Effects of environmental conditions on mechanical and physical properties of flax fibers," Compos. A Appl. Sci. Manuf. 32(8), 1105-1115. DOI: 10.1016/S1359-835X(01)00032-X

TAPPI T 203 cm-99 (2009). “Alpha-, beta- and gamma-cellulose in pulp,” TAPPI Press, Atlanta, GA.

TAPPI T 233 cm-01 (2001). "Pentosans in wood and pulp," TAPPI Press, Atlanta, GA.

TAPPI T 236 om-99 (1999). “Kappa number of pulp,” TAPPI Press, Atlanta, GA.

Thakur, V. K., Thakur, M. K., and Kessler, M. R. (2017). "Volume 8: Nanocomposites: Advanced applcations science and fundamentals" in: Handbook of Composites from Renewable Materials, V. K. Thakur, M. K. Thakur, and M. R, Kessler (eds.), Scrivener Publishing, Beverly, MA. DOI: 10.1002/9781119441632

Tronc, E., Hernández-Escobar, C. A., Ibarra-Gómez, R., Estrada-Monje, A., NavarreteBolaños, J., and Zaragoza-Contreras, E. A. (2007). "Blue agave fiber esterification for the reinforcement of thermoplastic composites," Carbohyd. Polym. 67(2), 245255. DOI: 10.1016/j.carbpol.2006.05.027

Yadama, V., Lowell, E. C., Peterson, N., and Nicholls, D. (2009). "Wood-thermoplastic composites manufactured using beetle-killed spruce from Alaska," Polym. Eng. Sci. 49(1), 129-136. DOI: 10.1002/pen.21231 
Zhang, H. H., Cui, Y., and Zhang, Z. (2013). "Chemical treatment of wood fiber and its reinforced unsaturated polyester composites," J. Vinyl Addit. Techn. 19(1), 18-24. DOI: $10.1002 / \mathrm{vnl} .20321$

Article submitted: July 17, 2019; Peer review completed: October 1, 2019; Revised version received and accepted: October 24, 2019; Published: October 28, 2019.

DOI: 10.15376/biores. 14.4.9806-9825 